\title{
Complete Oral Clearance
}

National Cancer Institute

\section{Source}

National Cancer Institute. Complete Oral Clearance. NCI Thesaurus. Code C127209.

A finding of complete oral clearance after swallowing. 